\title{
Urban Informal Food Traders: A Rapid Qualitative Study of COVID-19 Lockdown Measures in South Africa
}

\author{
Teurai Rwafa-Ponela *(D), Susan Goldstein (D), Petronell Kruger (D, Agnes Erzse, Safura Abdool Karim \\ and Karen Hofman
}

check for updates

Citation: Rwafa-Ponela, T.; Goldstein, S.; Kruger, P.; Erzse, A.; Abdool Karim, S.; Hofman, K. Urban Informal Food Traders: A Rapid Qualitative Study of COVID-19 Lockdown Measures in South Africa. Sustainability 2022, 14, 2294.

https://doi.org/10.3390/su14042294

Academic Editors: Mario D'Amico, Colin Michael Hall and Flavio Boccia

Received: 25 November 2021

Accepted: 28 January 2022

Published: 17 February 2022

Publisher's Note: MDPI stays neutral with regard to jurisdictional claims in published maps and institutional affiliations.

Copyright: (c) 2022 by the authors. Licensee MDPI, Basel, Switzerland. This article is an open access article distributed under the terms and conditions of the Creative Commons Attribution (CC BY) license (https:// creativecommons.org/licenses/by/ $4.0 /)$.
SAMRC/Wits Centre for Health Economics and Decision Science-PRICELESS SA, School of Public Health, Faculty of Health Sciences, University of the Witwatersrand, Johannesburg 2193, South Africa; susan.goldstein@wits.ac.za (S.G.); petronell.kruger@wits.ac.za (P.K.); agnes.erzse@wits.ac.za (A.E.); safura.abdoolkarim@wits.ac.za (S.A.K.); karen.hofman@wits.ac.za (K.H.)

* Correspondence: teurai.rwafa@wits.ac.za; Tel.: +27-11-717-2236

\begin{abstract}
Globally, the adoption of COVID-19 containment measures, such as lockdowns, have been used to curb the rapid spread of the pandemic. However, these action regulations have caused substantial challenges to livelihoods. We explored the perceptions and experiences of COVID-19 implications for urban informal food traders in South Africa during the initial lockdown period that lasted five weeks. A rapid qualitative study was conducted during October-November 2020. Twelve key informants (seven men and five women) categorized into informal traders and food system expert groups were interviewed. Data were analyzed thematically using MAXQDA software. Participants perceived informal trading as a main source of livelihood for many individuals. Negative lockdown impacts described included forced business closure, increased food costs and reduced demand. The consensus among participants was that the government's lack of formal recognition for informal food traders pre-COVID-19 contributed to challenges they faced during the pandemic, as evidenced by their exclusion as "essential service providers" at the start of lockdown. Policies that fail to recognize and consider informal food traders during 'normal' times lead to widened social inequality gaps among already vulnerable groups during natural disasters and disease outbreaks. In the case of COVID-19 in South Africa, this caused severe hunger, food insecurity and income loss.
\end{abstract}

Keywords: informal trade; COVID-19; lockdown measures; food system; sustainability

\section{Introduction}

Globally, the COVID-19 pandemic has impacted both how people live and earn a living. South Africa is no exception. Non-pharmaceutical public health interventions, including mobility, travel and trade restrictions ("lockdowns"), have been implemented to curb the spread of the disease [1]. These restrictions have caused severe disruptions to economic activity, resulting in adverse socio-economic consequences, such as loss of livelihoods and income $[2,3]$. This has exacerbated existing social disparities and created further inequality by pushing vulnerable people into extreme poverty [4-6]. In many countries, millions of people experienced increased food insecurity, particularly marginalized populations who rely on income from daily wage work, such as those in the informal sector [4-8].

The informal sector is a significant contributor to employment, income generation and economic development, particularly in low- and middle-income countries [9,10]. In Africa, the informal food system has been a lynchpin in food access and security for urban poor households $[3,11,12]$. In South Africa, $70 \%$ of poorer households in urban areas obtain some, if not all their food through the informal sector [13]. It is estimated that in South Africa the informal food sector accounts for $40-50 \%$ of food sales a year [14].

Despite its significance, the informal sector was rarely considered in developing COVID-19 responses. Scholars estimate that the impact on access to food in the informal 
sector during COVID-19 could be profound, as it is a primary food source for most lowincome households in urban townships $[13,15]$. Loss of income and livelihoods due to COVID-19 substantially reduced people's access to food and this is reflected in increased levels of food insecurity [16]. For example, food insecurity among the South African population increased from $4.3 \%$ to $7 \%$ during the initial lockdown period [17]. A similar trend was observed in other African countries, like Kenya and Uganda [18]. The driver of this trend appears to be the loss of income due to the pandemic rather than disruptions to the supply and formal components of the food system [19].

During the pandemic, severe impacts on economic and food systems, such as threats to sustainability and food security, have been reported [20-23]. This includes households reporting lower food availability, switching their main food supplier to farming and cooking less frequently during lockdown [22]. Solutions to achieve sustainable food systems have mainly been developed in high-income countries, where food systems are industrialized and formal, as opposed to lower and middle-income settings' food systems, which tend to be organized informally. Decision makers often marginalize the informal food system by failing to consider it as part of a job-creating market and disregarding its contribution to local food security [24]. Moreover, informal traders are not recognized or protected under labour legislation and social protection policies [25]. The informal sector is associated with socio-economic vulnerability [26] and occupational risk hazards [27], due to inadequate working conditions, such as limited access to water, sanitation and hygiene, as well as low and inconsistent daily incomes. Low wages are associated with an increased risk of food insecurity among informal traders [28-30]. Vulnerability of informal traders is exacerbated during emergency periods, like the COVID-19 pandemic. The literature suggests that the needs of informal traders are wide-ranging, from political to practical (improved water and sanitation) $[13,31-33]$. To ensure the sustained contribution of informal traders to local economies, markets and food systems, there is a need to increase support for the sector through active engagement to understand needs for priority setting.

There is a need to rethink how sustainable food systems are defined. The informal sector should be included in, if not at the centre of the reimaging. Given that African economies remain largely informal and extremely vulnerable to external shocks, there is a need to investigate the socio-economic impact of COVID-19 and its related policy responses in the sector [34]. Studies have shown that lockdowns had unintended consequences on vulnerable informal traders, adversely affecting food availability through various disruptions caused to trade and supply chains [3,16,35-37]. Disruptions to food environments emanate from personal and external dimensions of the food system [38]. Personal dimensions include geographical access, affordability, convenience and desirability of food; and external dimensions include food availability and quality, prices, vendors, markets and regulations [38]. While the impacts of COVID-19 and its policy responses on informal traders have been documented [12,27,39-41], there are notable gaps in emerging knowledge. There was also an increase in food insecurity, which is likely linked to disruptions in the informal food sector in urban areas [39,40,42].

South Africa's COVID-19 lockdown aligned with regional responses to the pandemic and there is evidence to show that traders operating in the informal food system were disproportionately affected by COVID-19 responses [21,23]. With the government implementation of the Stage 5 lockdown (the most extreme level) for five weeks (from midnight 26 March-31 April 2020) [43], South Africans were confined to their homes. Exceptions were granted for either seeking or providing "essential services or goods", such as food and healthcare [44]. Substantially, incremental lifts to lockdown restrictions and amendment of regulations were announced on a regular basis [5]. During initial 'hard' lockdown periods, informal food traders were not regarded as 'essential service providers' and therefore not allowed to operate [14]. This meant that large numbers of vulnerable informal traders suddenly became economically inactive [25]. Later, when permission to trade was granted for informal food traders [45], foot traffic at vending sites significantly reduced due to mobility restrictions, thereby affecting informal businesses [39]. Figure 1 indicates a timeline of 
COVID-19 lockdown regulations and their implications for the informal food system in South Africa.

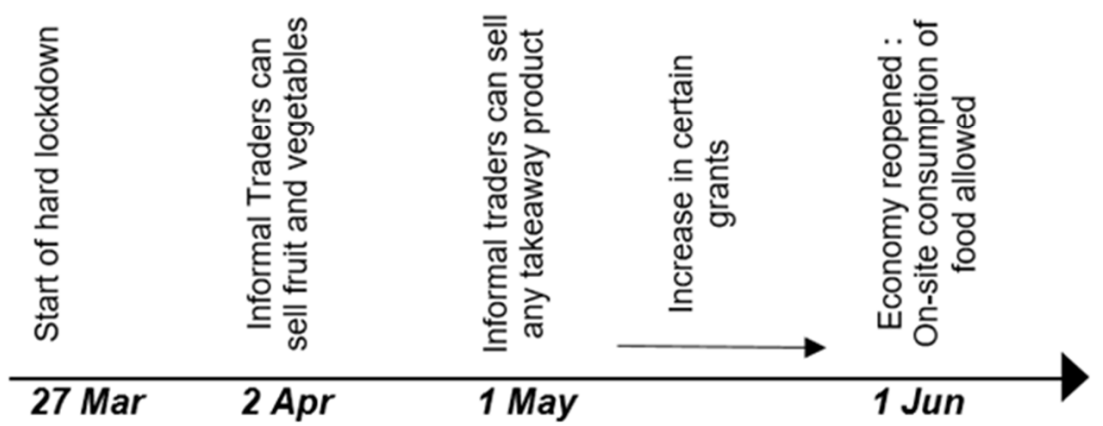

Figure 1. Timeline of key hard lockdown regulations that affected informal traders in South Africa.

These disruptions to the informal food sector were severe, particularly their implications for vulnerable populations, their unprecedented nature and their far-reaching impact on informal food trading. For this reason, it was important that the impact of the COVID-19 lockdown response and how it affected the informal food system be understood, including the demand-side implications of its sustainability and threats to food security among those who depend on the sector. The complexity of the informal food system is best understood through the perspective of the multiplicity of stakeholders engaged in the sector [46]. This paper proposes a starting point for governments and civil society to support the informal food sector by engaging local traders to better understand their needs and priorities.

Therefore, it remains critical to gain more clarity on the extent and depth of the COVID19-related disruptions and challenges faced within informal food systems [24], as they are both a source of livelihood and food in most urban settings. This qualitative study sought to provide these insights, which, until now, had remained on the margins of COVID-19 research. It is important to document such perceptions in preparation for similar future policy emergency mitigation responses [41]. These understandings may help, in particular, inform considerations of vulnerable populations, such as informal traders, to reduce severe consequences on urban food security in future pandemics $[12,13,39,47]$. In this study, we aimed to explore lived experiences and perceptions of disruptions caused by COVID-19 and the response to it on informal food traders in urban areas of three South African provinces during the initial lockdown period.

\section{Methods}

A rapid qualitative study was conducted over a one-month period to provide an in-depth understanding of the effects of COVID-19 and related lockdown measures on urban informal food trading in three South African provinces. Rapid qualitative studies generate knowledge under pressure, like the COVID-19 pandemic, to inform policy and practice [48]. Data for this study was collected as part of a larger project investigating the impact of COVID-19 on the South African food system [49].

\subsection{Conceptual Framework}

Ensuring food security in urban areas through informal food trading is critical. Therefore, there is a need to minimize the extent of both personal and external dimensions of disruptions in the informal food system [38]. In order to understand the consequences of COVID-19-related responses and how best to address future challenges to minimize consequences in the informal food system and enhance sustainability during a shock period like lockdown, we drew on a theoretical framework commonly used in food security analysis. We used the "six dimensions of food systems" framework proposed by the United Nations' High Level Panel of Experts (HLPE) on Food Security and Nutrition [7]. The framework was selected on the basis that it illustrates the interconnectedness of food security dimen- 
sions required to support a sustainable food system $[7,50]$. Table 1 provides the definition and characteristic of each of the six dimensions. A food system is defined as "all elements (environment, people, inputs, processes, infrastructures, institutions etc.) and activities that relate to the production, processing, distribution, preparation and consumption of food, and the output of these activities, including socio-economic and environmental outcomes" [51]. Specifically, the framework supported our research idea that recognizes the food environment in an informal system as a complex system operating within a wider food system. Given this complexity, reasons for disruptions to urban informal food trading activities and the implications of outcomes during a downtime, like lockdown, might be multifactorial [52]. Previously, the framework has been effectively used to analyze a similar research topic that described how policy responses to COVID-19 affected each element and activities in ensuring food security and sustainability in the informal food system alike [7]. This study explored the informal food system during the initial COVID-19 lockdown period in South Africa.

Table 1. Sustainable informal food systems that support the six interconnected dimensions of food security, Adapted from [7,50].

\begin{tabular}{ccc}
\hline Dimension & Characteristic & Definition \\
\hline Access & Equitable & Ability to acquire food in the informal food system \\
Availability & Productive and prosperous & Ability of informal food system to provide sufficient food \\
Stability & Diverse and resilient & Ability of informal food system to provide food during a sudden shock \\
Sustainability & Regenerative & Ability of informal food system to provide food in the long-term \\
Utilization & Healthy and nutritious & Ability of informal food system to meet food needs \\
Agency & Empowering & Ability of informal food system participants to exercise power \\
\hline
\end{tabular}

\subsection{Recruitment and Sampling}

Purposive sampling was used to select individuals who had knowledge of or experience with urban informal trading. This was done to ensure the recruitment of appropriate key informants who would provide rich study data. Our primary focus was on street and spaza/small shops trading in urban areas of South Africa. Informal food system stakeholders were stratified into two key informant categories: informal food traders or representatives of informal traders' organizations $(n=8)$ and food system experts in academia or advocates $(n=4)$. Both groups of informants were fairly homogenous [53]. The research team had no prior relationship with any of the participants before this study. Potential participants were contacted through telephone calls and invitation letters were sent via email. The purpose of the study was explained to each potential participant. In addition, a snowballing technique-a strategy whereby participants help identify other information-rich sources for recruitment into the study-was used. Sample size was determined by the data obtained and we sampled to informational redundancy [54,55]. At this point, sampling was terminated [55]. Recruitment of a smaller number of participants is justifiable in qualitative studies [53-58]. Qualitative sample sizes are considered adequate when they satisfy the following parameters: being large enough to enhance rich insights and small enough for an in-depth inquiry of the phenomenon under study $[56,59]$.

\subsection{Data Collection}

Data were collected between October and November 2020 using a semi-structured in-depth interview guide to understand how COVID-19 and related lockdown measures affected urban informal food traders in South Africa. Snowballing resulted in the selection of participants based in three provinces: Gauteng, Limpopo and Western Cape. These provinces are predominately urban. An experienced female qualitative senior researcher with a doctoral degree conducted the interviews. Interview questions focused on the perceived role of informal food traders in the economy and food system, experiences and perceptions of impacts of the COVID-19 lockdown on daily operations, challenges experienced due to lockdown restrictions and perceptions of the government's response 
to the pandemic. Interviews were conducted telephonically and audio-recorded. They lasted for an average of $30 \mathrm{~min}$. Audio files were transcribed verbatim. Notes were taken during the interviews. Key informants were recruited and invited to participate in the study to data saturation, a point where further data collection was deemed unnecessary. This assessment of data adequacy was determined by the researchers' judgement and prior experience with qualitative studies $[57,60]$. Twelve participants were interviewed for this study. There were no refusals to participate. We reached data saturation with the eighth interview among informal traders [48]. However, we continued to collect data from four additional key experts in food systems and informal trading to ensure that no new information could be elicited.

\subsection{Data Processing and Analysis}

Data were managed and analyzed using MAXQDA software (version 2020) [61]. Thematic analysis was conducted in a two-phased approach [62]. In the initial analysis phase, we used both deductive (guided by the interview guide) and inductive (content from the data) approaches to code the transcripts [63]. Transcripts were reviewed and initial draft coding was conducted. The emerging codes informed the development of an analytic codebook, which was refined by the researchers. Three of the research team members coded the transcripts using the final codebook that was organized into twelve coding families and 72 codes. The three compared and discussed their individual and collaborative coding, and any differences in coding were resolved through regular meetings. The coding process was followed by data extraction and analysis of findings. Relevant codes were identified and categorized into three major themes: (a) structure and functioning of informal traders' and the informal food environment, (b) key impacts of COVID-19 lockdown measures on informal food trading, and (c) feelings of lack of recognition of informal food traders before and during the COVID-19 pandemic. The entire research team engaged in further iterative analyses of the data. Quotes from participants are used to illustrate these themes [64]. During the second analysis phase, we used the six dimensions of the food systems framework to interpret our findings about how disruptions caused by the COVID-19 lockdown impacted on the sustainability of the urban informal food system. The framework helped guide our research by examining the topic against each dimension of the framework, as well as illustrating how the six dimensions related to each other based on the findings, focusing, in particular, on how COVID-19 disruptions affected the sustainability of the urban informal food system and the implications they had for food security during the initial lockdown period in South Africa.

\section{Findings}

\subsection{Study Participants}

The final sample of participants included seven men and five women. Two types of stakeholders participated in the study. The first group of key informants were informal traders and/or representatives of Informal Traders' Associations $(n=8)$. Of these, six were men and two were women. The second participant group were academics with a role in food systems and/or advocates of informal trade $(n=4)$. Of these, one was male and the other three female.

\subsection{Structure and Functioning of Informal Traders and the Informal Food Environment}

Participants identified the informal sector as the main source of employment for many. For most informal traders, the informal sector was their only option as a source of livelihood, as shown by their long-term involvement in the sector (up to 30 years). Participants believed that the informal sector had a significant role to play, as it is widespread geographically and located in convenient places not reached by their formal counterpart.

"The informal sector is one of the very, very important sector[s], both in the economy and in the life of South Africans. I mean all over where you walk, almost every place, you find one little informal trader by the corner." (15_KII Informal Traders Alliance) 
In addition, informants emphasized the significant role of informal traders in the food system through food provision. Participants identified women commonly known as "Food Mamas" as mostly responsible for selling hot food. Some informal traders owned small shops (spaza shops) that sell a wider range of food items, including basic groceries. In particular, informal food traders provided healthy food, like fresh produce, which is often difficult to access in poor urban areas, thus filling an important gap. Participants viewed informal food traders' contribution to easy-access and affordable fresh produce as valuable. They also considered informal traders as key mediators between farmers or markets and consumers in the food supply chain:

"They are very large distributors of fresh produce in particular... They far undercut the supermarkets in price. So, they are much cheaper and they are also much more flexible in their quantities they sell. And they are much more accessible in terms of location of them and things like that. So, they in my view perform a very essential function in ensuring that people have access to fresh produce at a more affordable cost than supermarkets do. So, that makes them very important." (05_KII Informal Trader Advocate)

Interviews showed that informal traders had an opportunity to become a member of a union; words such as 'alliance', 'platform', 'forum', 'association', or 'organization' were commonly used to describe groups of how informal traders are organized. Membership in these groups is usually based on the location where informal traders operate. Informal traders reported that these organizations played various roles, including empowerment: "So, there was a need for us to come together so that we [are] able to have a voice" (12_KII Informal Traders' Association). Being a member of one of these groups enabled the creation of social safety networks, with benefits such as collective bulk buying of items, including food, to ease procurement costs on individuals, participation in social clubs (stokvels) to ease financial insecurity and a place to report grievances.

\subsection{Key Impacts of COVID-19 Lockdown Restrictions on Informal Food Trading}

There was a consensus among participants that the informal food system faced various disruptions during the COVID-19 pandemic: " ... there were some disruptions within the market through the lockdown" (05_KII Informal Traders Advocate). Several sub-themes are used to describe key disruptions that affected informal food traders during the initial hard lockdown. Figure 2 shows key impacts of COVID-19 lockdown measures on the urban informal food system and threats to food security for people who depended on the sector in South Africa during the shock period.

Nevertheless, the unintended consequences of COVID-19 and mitigation measures on informal traders were far reaching. In Box 1, we highlight the disruptions experienced by an informal food trader operating in one of the central business districts (CBD) in Gauteng province. The informal food trader describes the sudden and severe adverse effects of being forced to stay at home without an income or emergency relief from the government. These effects were part of a ripple effect of various disruptions in the informal food system, as well as the supply and demand chain of food, as described by the participant.

This case narrative illustrates a number of negative issues caused by COVID-19 lockdown measures that were corroborated by other participants in the study, including: forced business closure, requirements for trading permits, harassment by law enforcers, prohibition of on-site consumption of food, increased procurement prices for business commodities, lower demand for food and difficulty in start-up finance, as well as feelings of limited government support for the informal sector. Descriptions of these disruptions and issues are unpacked in the sub-sections that follow. 


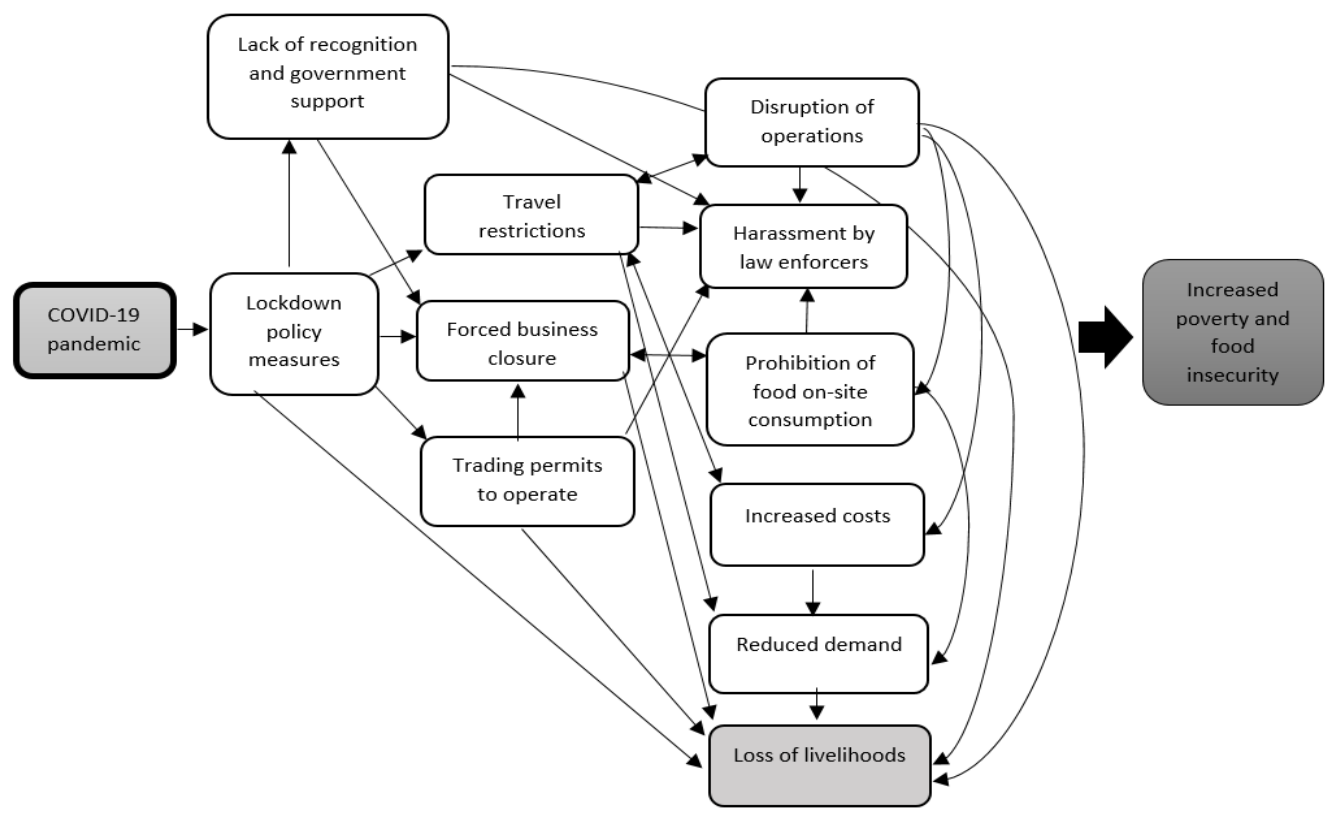

Figure 2. COVID-19 impacts on the urban informal food system that threatened food security in South Africa. Adapted from [7].

Box 1. Case Narrative: Impacts of COVID-19 and policy responses on a "Food Mama".

An informal food trader describes her business and experiences of how COVID-19 and lockdown restrictions affected it. The "lockdown" was protracted. "The problems started when they said more [than] 21 days ... Just imagine staying at home for six months without an income."

"My business is food vending ... I have been selling from 2009. I am selling pap, chicken, boerewors, beef, mogudu [intestines], magotwana [chicken feet], all of that. I am selling in the CBD [central business district] ... near the butcheries and near the shops. I buy my grocery at the shop called XX that is where I get mealie meal, milk, bread and other groceries. There is a XX butchery where I get the meat. I get my sauces at XX where I get my vegetables. Since COVID-19, the prices have gone up. The price of milk is up, the mealie meal price is up, all the prices are up, at the moment they [customers] are not coming, they are not coming 100\% to the office [working from home] .... Because of that, my business is down. Not only me, but all the informal traders in the street now, we are struggling. There are so many challenges. I have had to throw away food, even if I just cook one pot. It's month end as I speak to you but I do not have even R2000 [USD 135] in my hand. I must pay rent, I have kids who are going to school, and I must pay school fees, things like that. I used to cook like four pots a day [before lockdown], now I am only cooking two or one-and-half a day, that why I am saying we are struggling."

When informal traders were allowed back on the streets to operate, most did not have the financial means to get their business up and running again. "... [when] we needed to come back to the street we had to go to Mashonisa [loan sharks] to get the money so you can start to stock. We were not supposed to put tables and chairs; you were supposed to sell only takeaways. There are people who wanted to sit and didn't want to go and eat in the office but because rules are rules, you would tell them you are not allowed to sit, you need to go and only buy takeaways. That was a very big challenge. In the case of the other restaurants like $X X$ and $X X$, they deliver to the offices. In our [informal] business, we do not deliver. So, we lost a lot of customers."

In terms of government aid: "We only hear that there is this money from the government, but that money never reaches us, we do not know where that money ends. We do not know we only hear people talking about it but we have no information on it. I have heard from people that there are food parcels and things like that, but I have never found [received] or seen them. There is no one who would come to you as an informal trader and say that let's get you this and that [it never came]. The ZAR 350 [USD 25] that they have given for SASSA [Department of Social Development], I did not get it, not even once. I applied a couple of times and I did not get it." 


\subsubsection{Forced Closure of Businesses}

There was a general perception among participants that the role of informal traders in the food system remained overlooked by government officials during the lockdown. The initial phases of the hard lockdown period saw informal traders being forced to close their businesses and stay at home, as they were not categorized as essential service providers. This closure was unexpected and had profound impacts on income and livelihoods, as explained by a representative of an informal traders' organization: "The president announced the lockdown on the 26th of March [2020], without a warning. And that is where we get our future [livelihood] by being on the street. The business went down and people were affected" (11_KII Informal Traders Association). The forced closure of informal food trading while formal food providers like supermarkets remained open was perceived as discriminatory:

"Our government is so cruel ... Our people, the street vendors were forced to close. When you look at XX, XX, and XX [names of shops provided] and the malls. They are operating and they are selling food. Our members are affected by the situation of COVID-19 pandemic. They were not selling and they were staying at home." (11_KII Informal Traders Association)

A member from academia, stated the cruelty of the initial policy responses to COVID19 and reported a "Massive closing down of informal traders that in the beginning was barbaric" (08_KII Academia). Participants felt that it was better for informal food traders to be fending for themselves on the streets than keeping "safe" at home, while facing threats of hunger. The same academic stakeholder described this concern: "For me I am one of the people who thinks it's crazy to kill people through hunger, keeping them safe from the virus. But, you know that is a very personal view" (08_KII Academia). The closure of informal trading lasted only three weeks. Lobbying and advocacy from civil society groups led to the reversal of the discriminatory lockdown regulations and informal markets were reopened.

\subsubsection{Need for Trading Permits to Operate}

Subsequent easing of lockdown restrictions and changing emergency alert levels saw informal traders being allowed back on the streets in phases, depending on the types of goods sold. Informal traders were allowed to continue trading subject to obtaining a COVID-19-specific trading permit. In a system of changing COVID-19 regulations, some informal traders had to constantly adjust to updating regulations to comply with COVID-19 measures and to stay in business. For those who were not initially selling fresh produce, the change for profit margins meant learning a new way of doing business. Sharing her adaptation struggles, another informal trader described:

"When I resorted to selling fruit ... I had to take [purchase] it from other traders. And they were also making a killing [large profit] ... It was not easy to get stock." (12_KII Informal Traders Association)

While the introduction of trading permits allowed informal traders to operate; however, participants highlighted that neither informal traders nor local municipalities were prepared for the sudden introduction of a new permit system during a crisis. Securing COVID-19 trading permits was particularly challenging for informal traders, as described by this stakeholder:

"Some municipalities didn't have a permit system, so suddenly in the middle of a pandemic; they need to develop a permit system. Some had a permit system but they struggled to manage the issuing of the COVID permits." (05_KII Informal Traders Advocate)

Lack of information about the permit system was seen as another barrier:

"In many parts of the country people were told in order to trade they had to apply for permits. For several weeks traders around the country tried to go to municipal, [however] they didn't know what kind of permits to give them." (02_KII Academia)

Limited information on permits left informal traders feeling frustrated and unable to operate. Informal traders expressed the need for timely information on where to obtain 
trading permits and the types of documents required to make applications. Other participants believed that the challenges faced were due to mis-interpretations of the regulations by individual law enforcers, as described by this informal trader: "... I don't think the problem is the laws, I think the problem now is the perception of the individuals" (03_KII Informal Traders Alliance).

\subsubsection{Harassment by Law Enforcers and Travel Restrictions}

Several participants highlighted constant harassment of informal traders by law enforcement officers, even when operating with trading permits. The harassment included confiscation of goods: "It was difficult because the local police, the metro police, they used to take their stock" (11_KII Informal Traders Association). Another challenge reported by informal traders that affected business during this period was the placement of roadblocks, which restricted travel for informal trade. Travel restrictions had implications for access to food supplies. Regarding travel restrictions, one representative of an informal traders' union recounted challenges faced:

"The change is that they [informal traders] were not able to travel because of the police and the soldiers. They always stopped them. They were denying them with the road [restricted them to travel]." (03_KII Informal Traders Alliance)

In addition, participants felt unjust treatment of informal food traders who faced being arrested for trying to make a living on the streets: "In many cases police and law enforcement were either arresting people or fining people for trying to sell food" (02_KII Academia). Some participants highlighted the harassment of informal street traders by law enforcers as an existing challenge that was exacerbated by the COVID-19 pandemic.

\subsubsection{Prohibition of On-Site Consumption of Food}

Another lockdown regulation that affected day-to-day operations of informal food traders described by participants was the prohibition of on-site consumption of food. This meant that informal food traders were required to serve food in take-away containers or make deliveries. Participants felt that informal food traders had limited or no capacity to deliver food to their customers compared with formal "big" fast-food outlets. As a result, informal food traders lost their customer base. Given that most formal restaurants had an already existing food take-away system, participants felt this type of regulation was unjust for informal food traders as it left them at a disadvantage:

"The one[s] that sell their food, they cook in the street, they dish up in the street ... . we have to fight for them, because they are saying the restaurants must be opened, to do takeaways ... But it's impossible for informal traders to sell takeaways, because at those restaurants ...., they [customers] call and make orders." (07_KII Informal Traders' Platform)

\subsubsection{Increased Procurement Costs}

Participants described the limited availability of certain food items, fresh produce in particular, during the lockdown. On the one hand, this was perceived to result from lower levels of food production. On the other, informal traders stated that closure of some food markets further reduced places for procurement and competitiveness in provision of supplies. The result was increased procurement costs, forcing some informal food traders to close their businesses:

"At the moment, at the market the prices are high. The others have decided that they will wait till the market lowers its price.... Others are closed now because of the situation of prices." (11_KII Informal Traders Association)

As previously stated, informal food traders had to adapt their business operations and procurement practices to stay afloat. For example, some informal food traders shifted to collective buying and collection of fresh produce directly from farms. However, increased procurement prices and extra logistics limited the amount of goods informal food traders could stock. Inevitably, they were also forced to increase prices of commonly purchased 
food items, like tomatoes. This led to disgruntled customers and a reduction in purchases by consumers.

"If you go to the market and buy tomatoes at a higher price, and you come and sell at a higher price, people with start to query why you are selling at a higher price, while you got it at the market with a higher price." (11_KII Informal Traders Association)

In addition, some informal food traders indicated that increased procurement prices influenced their decisions on which items to buy and sell during the lockdown period. A spaza shop owner described this business phenomenon: "So when it comes to business you have to think, so this thing I want to buy how much will I buy it for and how much will I make from selling it" (18_KII Spaza Shop Owner). However, other participants were concerned that increased procurement costs had led to compromised food standards, as some informal food traders sought to increase profit margins by purchasing low-quality food items.

"I don't know whether, trying to make more money, they are buying very cheap mealie meal and so on. I know specifically about that [food] Mama ... I suspect people are starting to buy very cheap, some of them to minimize [costs]." (15_KII Informal Traders Alliance)

\subsubsection{Reduced Demand and Customer Base}

Participants reported that as people were required to stay at home during the COVID19 lockdown, informal food traders experienced a decreased customer base: "When the President started to open formally, the customers where no longer there" (11_KII Informal Traders Association). The increase in remote work for people in non-essential services left informal traders concerned about business sustainability:

"There might be some sort of structural changes that have longer term impacts, you know like, if a large proportion of people continue to work from home then obviously other business like street traders who depended on them ... the business is also down." (05_KII Informal Traders Advocate)

An informal trader described how previously crowded and busy areas, like taxi ranks, which were a hub of informal economic activity, suddenly became less busy. This was due to reduced foot traffic because of COVID-19 regulations on mobility and social distancing protocols:

“... [Before] people were able to make a business [living] ... You find places where people were able to be crowded now they are no longer able to go there... There are no longer in operation because of these COVID-19 laws." (03_KII Informal Traders Alliance)

Informal food traders highlighted how reduced demand for food by customers also influenced their decisions on which food items to buy and sell. A spaza shop owner described his experience of trying to sell certain food items that were no longer in high demand during lockdown, forcing him to adjust pricing and possible loss of profits:

"There are some stocks that you would buy and would normally sell fast, but during this time [lockdown] you find that they are not selling as they used to. So, you know you had to make sure that you at least sell them at the price that would sell. Because you would find that you are with stock for two weeks at the time that is not selling." (18_KII Spaza Shop Owner)

Reduced demand for food was compounded by increased losses of employment in the general population due to COVID-19, which further reduced purchasing power among regular customers of informal food traders: "Our customers are losing their jobs. I used to have many customers that have lost their jobs and some that are not yet back to work" (13_KII Informal Food Vendor). Therefore, reduced demand led to decreased daily income generation for informal food traders. This challenge had its own consequences, as described by this participant: "The economic impact means less money around which is affecting some business including food business" (05_KII Informal Traders Advocate). 


\subsubsection{Loss of Livelihoods}

Participants reported that the cumulative result of COVID-19 restrictions among informal traders, including those that sell food, was the loss of their sources of livelihood. Stakeholders from informal traders' associations described vendors who were not able to trade during lockdown who became food insecure while observing stay-at-home orders: "Our people are used to working for themselves, but at that point they were at home. It's difficult for them because they did not have food" (11_KII Informal Traders Association). This had poverty implications among an already economically vulnerable sub-population.

Some key stakeholders believed that women in the informal sector were affected more than their male counterparts. "I [am] thinking it has affected woman more" (08_KII Academia). Inability to operate during some period of the COVID-19 lockdown resulted in informal traders channeling their limited business capital to household expenses, like food, to survive. Loss of revenue to sustain business while staying at home made restarting informal businesses difficult:

"And one of the things that you take into account is that restarting for such a business is often difficult because these are not people with large amounts of capital. They stopped [operations]. I mean some lost stock, because stock doesn't last." (05_KII Informal Traders Advocate)

\subsubsection{Feelings of Lack of Recognition for Informal Traders before and during COVID-19}

There was a unanimous agreement among participants that the government displayed a deeply rooted lack of recognition for the important role played by informal traders in the economy, particularly the food system in South Africa. Participants described the continuous undervaluing and negative attitudes towards informal traders, including those who sell food, by those in positions of power as an ongoing challenge that existed even before COVID-19:

"We see this negative attitude towards street traders from the more senior politicians' right down to your metro policemen or policewomen who don't seem to mind taking stock that people have, and harassing them [informal traders] and so on. So, there is that kind of strong negative attitude towards them and undervalue of the contribution they make in the food system." (05_KII Informal Traders Advocate)

During COVID-19, the most apparent sign of lack of recognition of informal food traders was their initial exclusion from the list of essential goods and service providers. As a result, informal traders felt marginalized by decision makers: "Our government is so ignorant to us as the informal business, we were affected a lot" (11_KII Informal Traders Association). External stakeholders shared similar sentiments that informal food traders were unfairly treated during lockdown:

"The government tend to undermine them and not value them, as you saw with the COVID regulations. Because the government simply ignored. I don't know if they are not aware or what, but they ignored their roles." (05_KII Informal Traders Advocate)

In addition, leaders of informal traders' organizations reported that their members did not receive support, such as the COVID-19 emergency business relief, from the government during the lockdown period. Lack of support for informal traders included difficulties in accessing other types of government support, like food aid or the COVID-19 social relief grant. Participants highlighted the systematic exclusion of most informal businesses from COVID-19 support as a main underlying issue. This had implications for the sustainability of the informal food system during and after the pandemic. The "informal" status of traders meant they could not fulfil most of the requirements needed on the government online application systems to qualify for aid. Even the fact that it was an online system was exclusionary to vulnerable sub-populations, like informal traders. This is because for many, a smartphone or having internet connectivity is not a norm. 
"A big issue in terms of the business support, was that the structure of the business support that was there through Department of Small Business, was excluding small and informal business Because of all the requirements, and even doing it online and all the requirements you had to fulfil excluded a lot of the businesses." (05_KII Informal Traders Advocate)

A few big formal corporations were reported to have more power in the trade industry compared to small informal businesses. This left the informal sector with little or no agency, as described by this academic: "The power is concentrated in the corporate from the retail sector and a few powerful players; I think the system is very biased in their anatomy and that is what they do" (08_KII Academia). For example, despite having registered governance structures in the form of informal traders' organizations, traders felt continually side-lined:

"That why we are affiliated in SAITA [South African Informal Traders Alliance], so that maybe we can be assisted. But, now we are trapped, as they do not recognize the structure, which is formal. Even in our organization, in the sub-region, we have registered as an organization and we have the back up of SAITA but the government people just don't listen. It's so difficult we are stuffed." (11_Informal Traders Association)

\subsection{Impacts of COVID-19 on the Sustainability of Informal Food Systems}

Our findings show how ripple effects of lockdown regulations led to various disruptions in all six dimensions of the informal food system. Specifically, the food value chain had consequences on its sustainability. For example, lockdown orders disrupted the sustainability of informal food traders' operations. This was further compounded by a lack of government support for informal traders. Regulations like prohibition of onsite consumption had implications on utilization for informal food traders. Another significant challenge faced by informal food traders that had implications for the agency of the sector, as it was being recognized as a non-essential service. In addition, travel restrictions had impacts on access to food for both informal traders and those who rely on the sector for food supply. In Figure ??, we highlight the interconnectedness of the impacts of COVID-19 measures on the six dimensions of food security in the urban informal food system during the initial hard lockdown period in South Africa.

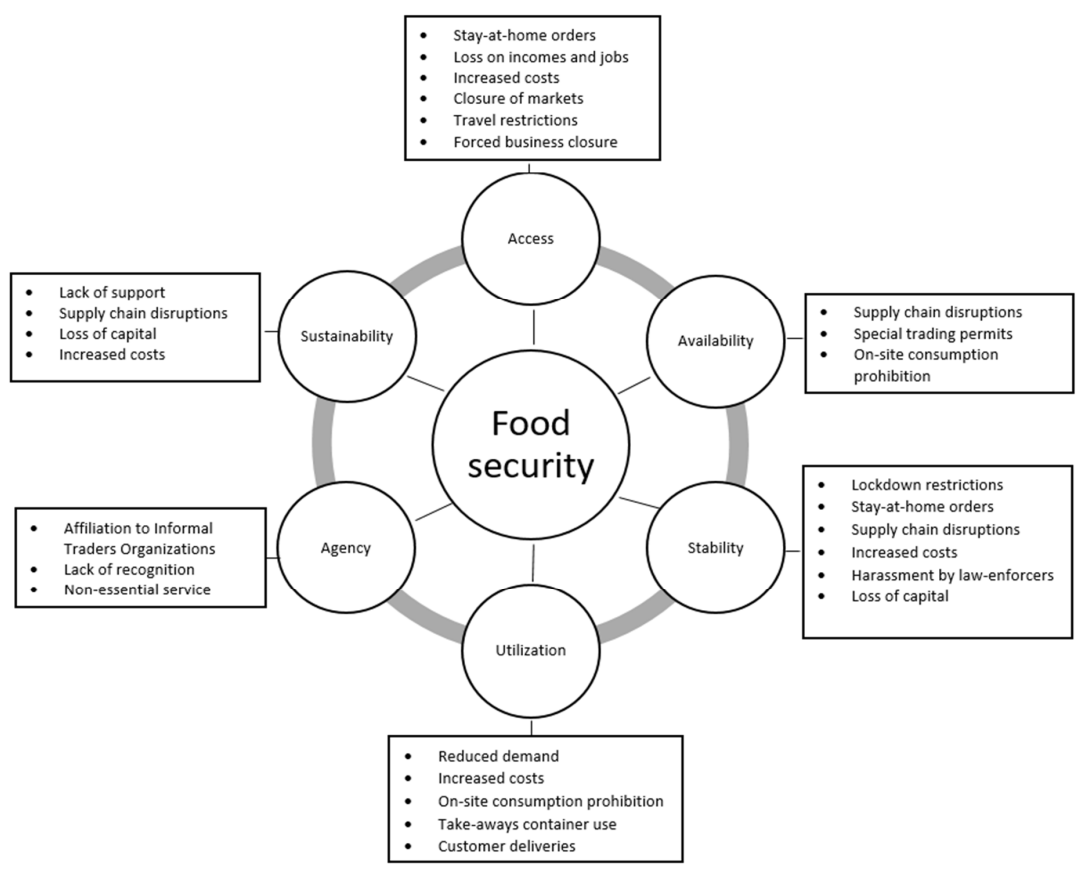

Figure 3. Key impacts of COVID-19 measures on the six interconnected dimensions of food security in the urban informal food system during lockdown in South Africa. Adapted from [7,50]. 


\section{Discussion}

This study reports informal food traders' experiences and perceptions of adverse consequences of South Africa's lockdown policies implemented in response to COVID-19 in urban areas. The analysis revealed the immediate economic impacts on the livelihoods of informal food traders and the challenges they faced to sustain business during and after the shock. We found that informal traders, who were already marginalized, were excluded from government support and a positive assessment of playing a role in the broader economy and food system and therefore pushed further out of the food system during lockdown. This had severe consequences for the sustainability of the informal food system, for both informal traders and urban poor communities who rely on the sector.

Our findings resonate with the experiences of informal traders in other low- and middle-income countries during the COVID-19 pandemic. Several African countries introduced unsupportive lockdown measures at the beginning of the pandemic [3], through clearing informal traders from the street and forcing them to close their businesses. In contrast, the Ghanaian, Ugandan and Rwandan governments recognized the critical contribution informal traders make to food security and ensured that informal food trading continued with extra measures, such as regular disinfection, allowing traders to sleep over, or decongesting informal food markets $[3,27,47]$. In the context of prolonged COVID-19 lockdown restrictions and an unprecedented unemployment rate of $44 \%$ in South Africa, the highest in the world [65], informal trading has become not only a question of day-to-day economic activity $[3,35,36]$ but also a question of survival for informal traders and their families $[6,36,66]$.

Historically, informal traders have been reported to have unique vulnerabilities to external shocks, such as state oversight $[6,27,34]$ and hostility [67]. For example, police harassment was described as a common experience for the informal sector in developing countries pre-COVID-19 [68]. Furthermore, in Brazil and Nigeria, financial stimulus packages provided fewer benefits to people working in the informal sector [37], while in Thailand informal traders faced systematic challenges that excluded them from registration processes on online government support platforms during the pandemic [6]. This study demonstrates a similar tendency of marginalization of informal traders pre- and during the initial COVID-19 lockdown period in South Africa. This highlights a key reason for the disproportionate challenges that hindered the sustainability of the informal food system during the initial lockdown period and an associated increase in hunger of an estimated 10 million people living in households affected by food insecurity [42]. Study participants' perceptions were in line with other South African studies that describe the neglect of informal traders by COVID-19 policies at times of desperate need of emergency assistance and social support to compensate revenue loss [34,37,41,69-72]. The passive exclusion of people working in the informal sector from financial and social protection during the pandemic worsened negative socio-economic impacts [69]. Inadequate social insurance is an example of an unintended effect of COVID-19 lockdown measures that left vulnerable groups, like informal traders, food insecure [25,73].

Despite these unique vulnerabilities, some informal traders were able to respond to disruptions caused by COVID-19 and lockdown. The informal sector is considered more agile compared to the formal sector [24]. It is also believed to serve as a shock absorber or buffer to people falling out of formal employment or experiencing financial hardship [41,71,74]. The COVID-19 pandemic and its lockdown regulations heavily tested informal traders' resilience and coping mechanisms. Some informal traders demonstrated sufficient agility and managed to continue working or adapt their functioning during lockdown periods in some sub-Saharan African countries, like Nigeria and Ghana [3]. Furthermore, to overcome the decreasing accessibility of supplies in the market during lockdown, some informal traders were forced to increase prices for basic necessities, like food. Other informal traders explored trading new products, such as fresh produce, or employed new delivery methods of supplies, similar to Thailand [6]. Less successful mechanisms were observed in Nigeria and Uganda, where there was borrowing of money from loan sharks to compensate for the lack of revenue and 
enable restocking of food products [6,27,75]. A similar example of coping was described during this study (see Box 1, Case Narrative). Lack of social support pushed informal food traders into debt $[31,69,75]$. Examples of seemingly agile informal food traders' inability to sustain their businesses during the pandemic have underscored the desperate need for social and financial support from the government $[3,47,75]$. Evidence from before and during the pandemic clearly indicated that the income earned by informal traders ill-prepared them for negative economic challenges [29]. With little or no savings and with restricted access to finance and bank accounts $[3,32,68]$, informal traders are left without means to mitigate livelihood risks, such as shocks experienced during the COVID-19 lockdown.

Discussions around sustainable development and access to food cannot overlook the key role of the informal food sector, as to do so would be to underestimate the adverse and long-lasting effects of leaving informal food traders in the margins for the duration of COVID-19 policy measures $[27,76]$. The contribution of informal food traders goes beyond their own employment to the food security of citizens who depend on the sector. In this context, informal traders are an asset to the sustainability of food systems, particularly urban poor communities in low- and middle-income settings. The impact of a weak relationship between the state and informal traders was evident in our study findings of limited engagement of informal traders in policy planning. This is despite the South African Government's commitment to the International Labour Organization (ILO) R204 recommendation, which includes, among other items, "providing rights, protections and incentives for informal workers, and recognizing the need for a friendly legal and policy environment" [77]. In South Africa, the consequences of not recognizing the role of the informal food sector was serious, not only for the informal traders but also for poor people countrywide, exacerbating vulnerability during lockdown responses [27,33].

\subsection{Recommendations}

In a time of crisis, it is very important to engage with both formal and informal sectors to gauge what the impact of proposed policy interventions might be on different subpopulation groups. Despite the time limitations, this paper demonstrated the consequences of not engaging with informal food traders or their respective unions. In addition, an increased recognition of the critical role played by informal traders in the local economy and food system is required with the urgent implementation of the ILO R204 in the country. This would involve a structured approach, including the policy of "do no harm", and the implementation of existing social protection systems to cater for informal food traders. It may be critical to consider that operating informally for traders in South Africa may mean a preference not to be regulated. Improved communication with informal traders, particularly at the local government level, would assist with alleviating some of the problems encountered by informal food traders. A hard look at the South African food system is required, not only to ensure that people are protected from hunger during economic shocks but also to ensure sustainable access to healthy and affordable food for the majority of vulnerable populations in the country.

\subsection{Study Strengths and Limitations}

Given the rapid nature of this study and that public responses to COVID-19 are continuously evolving, these interviews represent perceptions and experiences of participants collected during a specific moment in time-during the early phases of a national hard lockdown (Stage 5) in South Africa. A strength of the study was hearing the voices of those most affected and at a time when the impact was fresh in their minds. Some of the challenges faced during this research included recruiting informal traders who did not hold a position within an informal traders' organization. This is because these positions tended to be bureaucratic, with associated power dynamics. For example, leaders of associations saw themselves as "speakers" for their group members instead of referring the researchers to other informal food traders operating on the ground with whom we could have conducted interviews. In addition, some representatives were not directly involved 
with the trading of food. However, inclusion of experts in the food system and governance and/or advocates for informal trading provided a critical aspect to the study. Finally, we also could not sufficiently comment on the sustainability of the informal food system before the COVID-19 pandemic.

\section{Conclusions}

Our findings highlight the serious consequences of excluding key food system actors, informal food traders, from COVID-19 policy planning processes in South Africa. Continued lack of recognition of informal food traders combined with lockdowns and restrictive movements impacted the livelihoods and food security not only of informal traders but also the majority of urban poor communities whose only source of food is the informal sector. Going forward, informal traders cannot be left at the margins. For economic recovery, sustained growth and food security, informal food traders must be recognized. In face of possible future shocks, more inclusive emergency preparedness and support is required for South African informal traders. Failure to do so will widen social inequality gaps, particularly in the cases of those most vulnerable, through hindering the economic viability of traders' livelihoods and the access to food by the poorest households in urban areas. Revisiting and revising social and financial protection measures to include informal traders is a good starting point. In doing so, informal food traders should be consulted and their lived experiences should inform future policy planning.

Author Contributions: T.R.-P. collected the data, conducted data analysis and the initial writeup of first drafts of the manuscript. S.G. contributed to the writing and commented on drafts of the manuscript P.K. contributed to the writing and commented on drafts of the manuscript. A.E. contributed to the writing and commented on progressive drafts of the manuscript. S.A.K. contributed to data analysis and commented on progressive drafts of the manuscript. K.H. commented on drafts of the manuscript. All authors have read and agreed to the published version of the manuscript.

Funding: The International Development Research Centre (Grant Number: 108424-001) funded this study. Additional financial support came from the SAMRC/Wits Centre for Health Economics and Decision Science-PRICELESS SA (Grant Number: 23108).

Institutional Review Board Statement: The study was conducted according to the guidelines of the Declaration of Helsinki, and approved by the Human Research Ethics Committee (Medical) of the University of the Witwatersrand (protocol code M200847, approved 13 October 2020).

Informed Consent Statement: Informed consent was obtained from all informants involved in the study. All participants were provided with full information about the study. They participated voluntarily and provided informed consent to participate, as well as to audio-recording and transcription, prior to the interview being conducted. Anonymity of participants was ensured by using unique study identifiers.

Data Availability Statement: Data is available from the authors upon reasonable request.

Acknowledgments: Authors are grateful to participants for their valuable time and contributions during the study.

Conflicts of Interest: The authors have no competing interests to declare.

\section{References}

1. Shrestha, N.; Shad, M.Y.; Ulvi, O.; Khan, M.H.; Karamehic-Muratovic, A.; Nguyen, U.-S.D.; Baghbanzadeh, M.; Wardrup, R.; Aghamohammadi, N.; Cervantes, D.; et al. The Impact of COVID-19 on Globalization. One Health 2020, 11, 100180. [CrossRef] [PubMed]

2. World Bank. Global Economic Prospects; World Bank: Washington, DC, USA, 2020.

3. Megersa, K. The Informal Sector and COVID-19 in Sub-Saharan Africa. Knowledge, Evidence and Learning for Development, Institute for Development. 2020. Available online: https://opendocs.ids.ac.uk/opendocs/bitstream/handle/20.500.12413/15725 /890_informal_sector_and_COVID-19_Final.pdf?sequence=5\&isAllowed=y (accessed on 10 September 2021).

4. Ashford, N.A.; Hall, R.P.; Arango-Quiroga, J.; Metaxas, K.A.; Showalter, A.L. Addressing Inequality: The First Step Beyond COVID-19 and Towards Sustainability. Sustainability 2020, 12, 5404. [CrossRef]

5. Ebrahim, A. COVID-19 and Socioeconomic Impact in Africa: The Case of South Africa. Wider Backgr. Note 2020, 2. [CrossRef] 
6. Komin, W.; Thepparp, R.; Subsing, B.; Engstrom, D. COVID-19 and Its Impact on Informal Sector Workers: A Case Study of Thailand. Asia Pac. J. Soc. Work. Dev. 2021, 31, 80-88. [CrossRef]

7. HLPE. Impacts of COVID-19 on Food Security and Nutrition: Developing Effective Policy Responses to Address the Hunger and Malnutrition Pandemic; HLPE: Rome, Italy, 2020.

8. International Labour Organization. COVID-19 and the World of Work: Country Policy Responses; ILO: Geneva, Switzerland, 2020.

9. International Labour Organization. Informal Economy: More Than 60 Per Cent of the World's Employed Population Are in the Informal Economy; ILO: Geneva, Switzerland, 2018.

10. International Labour Office. Resolution concerning the measurement of employment in the informal sector. In Proceedings of the Fifteenth International Conference of Labour Statisticians, Geneva, Switzerland, 19-28 January 1993.

11. Crush, J.; Young, G. Resituating Africa's urban informal food sector. In Urban Forum; Springer: Berlin, Germany, 2019.

12. Resnick, D. COVID-19 Lockdowns Threaten Africa's Vital Informal Urban Food Trade; International Food Policy Research Institute: Washington, DC, USA, 2020; pp. 73-74.

13. Battersby, J.; Marshak, M. Mapping the Invisible: The Informal Food Economy of Cape Town, South Africa; Southern African Migration Programme; African Books Collective: Oxford, UK, 2017.

14. Wegerif, M.C. "Informal" Food Traders and Food Security: Experiences from the COVID-19 Response in South Africa. Food Secur. 2020, 12, 797-800. [CrossRef]

15. Peyton, S.; Moseley, W.; Battersby, J. Implications of Supermarket Expansion on Urban Food Security in Cape Town, South Africa. Afr. Geogr. Rev. 2015, 34, 36-54. [CrossRef]

16. Adhikari, J.; Timsina, J.; Khadka, S.R.; Ghale, Y.; Ojha, H. COVID-19 Impacts on Agriculture and Food Systems in Nepal: Implications for SDGs. Agric. Syst. 2021, 186, 102990. [CrossRef]

17. Stats, S.A. Loss of Income Resulting from the COVID-19 Pandemic May Lead to Higher Levels of Food Insecurity SA. 2020. Available online: http:/ / www.statssa.gov.za/?p=13327 (accessed on 15 August 2021).

18. Kansiime, M.K.; Tambo, J.A.; Mugambi, I.; Bundi, M.; Kara, A.; Owuor, C. COVID-19 Implications on Household Income and Food Security in Kenya and Uganda: Findings from a Rapid Assessment. World Dev. 2021, 137, 105199. [CrossRef]

19. Mogues, T. Food Markets During COVID-19; International Monetary Fund: Washington, DC, USA, 2020.

20. Mayasari, N.R.; Ho, D.K.N.; Lundy, D.J.; Skalny, A.V.; Tinkov, A.A.; Teng, I.; Wu, M.-C.; Faradina, A.; Mohammed, A.Z.M.; Park, J.M. Impacts of the COVID-19 Pandemic on Food Security and Diet-Related Lifestyle Behaviors: An Analytical Study of Google Trends-Based Query Volumes. Nutrients 2020, 12, 3103. [CrossRef]

21. WIEGO. Wiego's informal economy podcast: Social protection. In Protecting Informal Workers Amid the Global Pandemic; Roever, S., Ed.; Women in Informal Employment, Globalizing and Organizing (WIEGO): Manchester, UK, 2020.

22. Shupler, M.; Mwitari, J.; Gohole, A.; de Cuevas, R.A.; Puzzolo, E.; Čukić, I.; Nix, E.; Pope, D. COVID-19 Impacts on Household Energy \& Food Security in a Kenyan Informal Settlement: The Need for Integrated Approaches to the SDGs. Renew. Sustain. Energy Rev. 2021, 144, 111018.

23. Picchioni, F.; Goulao, L.F.; Roberfroid, D. The Impact of COVID-19 on Diet Quality, Food Security and Nutrition in Low and Middle Income Countries: A Systematic Review of the Evidence. Clin. Nutr. 2021. [CrossRef]

24. CDE. The Growth Agenda: South Africa's Informal Sector in the Time of COVID-19; Bernstein, A., Ed.; CDE: Johannesburg, South Africa, 2020; pp. 1-8.

25. Etim, E.; Daramola, O. The Informal Sector and Economic Growth of South Africa and Nigeria: A Comparative Systematic Review. J. Open Innov. Technol. Mark. Complex. 2020, 6, 134. [CrossRef]

26. Rogan, M.; Skinner, C. The size and structure of the South African informal sector 2008-2014: A labour-force analysis. In The South African Informal Sector: Creating Jobs, Reducing Poverty; Fourie, F., Ed.; Human Sciences Research Council (HSRC) Press: Pretoria, South Africa, 2018; pp. 77-102.

27. Resnick, D.; Spencer, E.; Siwale, T. Informal Traders and COVID-19 in Africa: An Opportunity to Strengthen the Social Contrac; IGC Policy Brief; International Growth Centre (IGC): London, UK, 2020; Available online: https://www.theigc.org/wp-content/ uploads/2020/08/Resnick-et-al-2020-Policy-Brief.pdf (accessed on 25 August 2021).

28. Horwood, C.; Haskins, L.; Hinton, R.; Connolly, C.; Luthuli, S.; Rollins, N. Addressing the Interaction between Food Insecurity, Depression Risk and Informal Work: Findings of a Cross-Sectional Survey among Informal Women Workers with Young Children in South Africa. BMC Women's Health 2021, 21, 1-12.

29. Pillay, V.; Rogan, M.; von Broembsen, M. Informal Economy/Sector; Institute for Economic Justice (IEJ): Johannesburg, South Africa, 2018; Available online: https:/ /iej.org.za/wp-content/uploads/2020/07/Stream-3-Policy-Brief-1-Informal-Economy-Sector.pdf (accessed on 10 September 2021).

30. Rogan, M.; Skinner, C. The Nature of the South African Informal Sector as Reflected in the Quarterly Labour-Force Survey, 2008-2014; University of Cape Town: Cape Town, South Africa, 2017.

31. Luke, D.; Masila, G.; Sommer, L. Informal Traders: A Balancing Act of Survival. African Bus. 2020, 1-8.

32. WIEGO. Impact of Public Health on Measures on Informal Workers' Livelihoods and Health; WIEGO: Manchester, UK, 2020.

33. Skinner, C. Informal-sector policy and legislation in South Africa: Repression, omission and ambiguity. In The South African Informal Sector: Creating Jobs, Reducing Poverty; Human Sciences Research Council: Pretoria, South Africa, 2018 ; pp. 412-438.

34. African Union. Impact of the Coronavirus (COVID-9) on the African Economy; African Union: Addis Ababa, Ethiopia, 2020; pp. 1-35. 
35. Akuoko, P.B.; Aggrey, V.; Amoako-Arhen, A. Ghana's Informal Economic Sector in the Face of a Pandemic. Soc. Sci. Humanit. Open 2021, 3, 100094. [CrossRef]

36. Ezimma, K.N.; Ifeanyi, E.A.O.; Anugwu, C.C. Informal Sector and Nigerian Economic Prospects: The Covid-19 Experience. Eur. J. Bus. Manag. Res. 2020, 5, 1-5. [CrossRef]

37. Ferreira dos Santos, G.; de Santana Ribeiro, L.C.; Barbosa de Cerqueira, R. The Informal Sector and COVID-19 Economic Impacts: The Case of Bahia, Brazil. Reg. Sci. Policy Pract. 2020, 12, 1273-1285. [CrossRef]

38. Turner, C.; Aggarwal, A.; Walls, H.; Herforth, A.; Drewnowski, A.; Coates, J.; Kalamatianou, S.; Kadiyala, S. Concepts and Critical Perspectives for Food Environment Research: A Global Framework with Implications for Action in Low-and Middle-Income Countries. Glob. Food Secur. 2018, 18, 93-101. [CrossRef]

39. Babalola, M.A.; Mcata, B.; Maila, M. The Impact of COVID-19 on Informal Food Traders in SA. HSRC Rev. 2021, $19,40-41$.

40. Khambule, I. The Effects of COVID-19 on the South African Informal Economy: Limits and Pitfalls of Government's Response. Loyola J. Soc. Sci. 2020, 34, 95-109.

41. Rogan, M.; Skinner, C. The COVID-19 Crisis and the South African Informal Economy: 'Locked Out' of Livelihoods and Employment; National Income Dynamics Study-Coronavirus Rapid Mobile Survey (NIDS CRAM): Cape Town, South Africa, 2020.

42. Spaull, N.; Daniels, R.C.; Ardington, C.; Branson, N.; Breet, E.; Bridgman, G.; Brophy, T.; Burger, R.; Burger, R.; Casale, D.; et al. Synthesis Report NIDS-CRAM Wave 5. In National Income Dynamics Study (NIDS)-Coronavirus Rapid Mobile Survey (CRAM); Southern Africa Labour \& Development Research Unit (SALDRU): Cape Town, South Africa, 2021; Available online: https://cramsurvey. org/wp-content/uploads/2021/07/1.-Spaull-N.-Daniels-R.-C-et-al.-2021-NIDS-CRAM-Wave-5-Synthesis-Report.pdf (accessed on 10 August 2021).

43. Kruger, P.; Moyo, K.; Mudau, P.; Pieterse, M.; Spies, A. Republic of South Africa: Legal Response to COVID-19; Oxford University: Oxford, UK, 2021.

44. Republic of South Africa. Disaster Management Act, 2002: Amendment of Regulations Issued in Terms of Section 27(2), Department of Co-operative Governance and Traditional Affairs, D.o.C.-o.G.a.T., ed.; Government Gazette: Pretoria, South Africa, 2020; No. R. 419 (43148/ R.398); pp. 1-3.

45. Republic of South Africa. Disaster Management Act, 2002: Amendment of Regulations Issued in Terms of Section 27(2), Department of Co-operative Governance and Traditional Affairs, D.o.C.-o.G.a.T., ed.; Government Gazette: Pretoria, South Africa, 2020; No. R. 446 (43199/R.446); pp. 1-15.

46. Fanzo, J.; Covic, N.; Dobermann, A.; Henson, S.; Herrero, M.; Pingali, P.; Staal, S. A Research Vision for Food Systems in the 2020s: Defying the Status Quo. Glob. Food Secur. 2020, 26, 100397. [CrossRef]

47. WIEGO. Pandemic Adds to Informal Vendors' Challenges; Women in Informal Employment, Globalizing and Organizing (WIEGO): Manchester, UK, 2020.

48. Vindrola-Padros, C.; Chisnall, G.; Cooper, S.; Dowrick, A.; Djellouli, N.; Symmons, S.M.; Martin, S.; Singleton, G.; Vanderslott, S.; Vera, N. Carrying out Rapid Qualitative Research During a Pandemic: Emerging Lessons from COVID-19. Qual. Health Res. 2020, 30, 2192-2204. [CrossRef]

49. Abdool Karim, S.; Erzse, A.; Kruger, P.; Rwafa-Ponela, T.; Tugendhaft, A.; Nyatela, A.; Nqakala, S.; Stacey, N.; Hofman, K.; Goldstein, S. The Impact of COVID-19 on Food Aid Systems in South Africa: A Cross-Sectional Mixed-Methods Study; SAMRC/Wits Centre for Health Economics and Decision Science-PRICELESS SA, School of Public Health, Faculty of Health Sciences, University of the Witwatersrand: Johannesburg, South Africa, 2022.

50. HLPE. Food Security and Nutrition: Building a Global Narrative Towards 2030; HLPE: Rome, Italy, 2020; pp. 1-112.

51. HLPE. Food Losses and Waste in the Context of Sustainable Food Systems. A Report by the High Level Panel of Experts on Food Security and Nutrition of the Committee on World Food Security; HLPE: Rome, Italy, 2014; pp. 1-117.

52. Legwegoh, A.F.; Riley, L. Food, Place, and Culture in Urban Africa: Comparative Consumption in Gaborone and Blantyre. J. Hunger Environ. Nutr. 2014, 9, 256-279. [CrossRef]

53. Boddy, C.R. Sample Size for Qualitative Research. Qual. Mark. Res. 2016, 19, 44-64. [CrossRef]

54. Hennink, M.M.; Kaiser, B.N.; Marconi, V.C. Code Saturation Versus Meaning Saturation: How Many Interviews Are Enough? Qual. Health Res. 2017, 27, 591-608. [CrossRef]

55. Lincoln, Y.S.; Guba, E.G. Naturalistic Inquiry; SAGE: Thousand Oaks, CA, USA, 1985.

56. Crouch, M.; McKenzie, H. The Logic of Small Samples in Interview-Based Qualitative Research. Soc. Sci. Inf. 2006, 45, 483-499. [CrossRef]

57. Vasileiou, K.; Barnett, J.; Thorpe, S.; Young, T. Characterising and Justifying Sample Size Sufficiency in Interview-Based Studies: Systematic Analysis of Qualitative Health Research over a 15-Year Period. BMC Med. Res. Methodol. 2018, 18, 1-18. [CrossRef]

58. Marshall, B.; Cardon, P.; Poddar, A.; Fontenot, R. Does Sample Size Matter in Qualitative Research? A Review of Qualitative Interviews in Is Research. J. Comput. Inf. Syst. 2013, 54, 11-22.

59. Sandelowski, M. Sample Size in Qualitative Research. Res. Nurs. Health 1995, 18, 179-183. [CrossRef]

60. Malterud, K.; Siersma, V.D.; Guassora, A.D. Sample Size in Qualitative Interview Studies: Guided by Information Power. Qual. Health Res. 2016, 26, 1753-1760. [CrossRef]

61. VERBI Software. MAXQDA 2020 [Computer Software]. 2019. Available online: https:/ / maxqda.com (accessed on 5 September 2020) 
62. Hsieh, H.-F.; Shannon, S.E. Three Approaches to Qualitative Content Analysis. Qual. Health Res. 2005, 15, 1277-1288. [CrossRef] [PubMed]

63. Chandra, Y.; Shang, L. Inductive coding. In Qualitative Research Using R: A Systematic Approach; Springer: Berlin, Germany, 2019; pp. 91-106.

64. Tong, A.; Sainsbury, P.; Craig, J. Consolidated Criteria for Reporting Qualitative Research (COREQ): A 32-Item Checklist for Interviews and Focus Groups. Int. J. Qual. Health Care 2007, 19, 349-357. [CrossRef] [PubMed]

65. Naidoo, P. South Africa's Unemployment Rate Is Now Highest in the World. 24 August 2021. Available online: https://www. bloomberg.com/news/articles/2021-08-24/south-african-unemployment-rate-rises-to-highest-in-the-world (accessed on 22 September 2021).

66. Das, M.; Chu, P.L.; Santos, G.-M.; Scheer, S.; Vittinghoff, E.; McFarland, W.; Colfax, G.N. Decreases in Community Viral Load Are Accompanied by Reductions in New HIV Infections in San Francisco. PLoS ONE 2010, 5, e11068. [CrossRef]

67. Skinner, C.; Balbuena, P. Where are the Inclusive Cities? Street Vendors Globally Face Increasing Hostility; WIEGO: Cambridge, MA, USA, 2019.

68. Mukhtarova, T. COVID-19 and the Informal Sector: What It Means for Women Now and in the Future; Georgetown Institute for Women, Peace and Security, Policy Brief: Washington, DC, USA, 2020; Available online: https:/ /giwps.georgetown.edu/wp-content/ uploads/2020/07/GIWPS_Covid19_July2020.pdf (accessed on 25 September 2021).

69. Ekeruche, M.A. Drivers of Disparity: How Policy Responses to COVID-19 Can Increase Inequalities. 2020. Available online: https:/ / media.africaportal.org/documents/Policy-Briefing-01-ekeruche_1.pdf (accessed on 25 September 2021).

70. UNDP. COVID-19 in South Africa: Socioeconomic Impact Assessment; UNDP: Pretoria, South Africa, 2020.

71. Lakshmi Ratan, A.; Roever, S.; Jhabvala, R.; Sen, P. Evidence Review of COVID-19 and Women's Informal Employment: A Call to Support the Most Vulnerable First in the Economic Recovery; Bill \& Melinda Gates Foundation: Washington, DC, USA, 2021.

72. Gruzd, S.; Bosman, I.; Zikalala, N.M. Regions Apart: How South Africa and Nigeria Responded to COVID-19. 2020. Available online: https://www.jstor.org/stable/resrep28259?seq=1\#metadata_info_tab_contents (accessed on 10 August 2021).

73. Barnett-Howell, Z.; Watson, O.J.; Mobarak, A.M. The Benefits and Costs of Social Distancing in High-and Low-Income Countries. Trans. R. Soc. Trop. Med. Hyg. 2021, 115, 807-819. [CrossRef]

74. Mróz, B. Beauty and the Beast: Is Shadow Economy a Shock Absorber under Economic Slowdown? Evidence from Poland. Int. J. Trade Glob. Mark. 2015, 8, 79-96. [CrossRef]

75. Bishi, H.; Grossman, S.; Startz, M. How COVID-19 Has Affected Lagos Traders: Findings from High Frequency Phone Surveys. Policy brief, NGA-20075 IGC and Lagos Trader Project. 2020. Available online: https://www.theigc.org/wp-content/uploads/ 2020/07 / Bishi-et-al-policy-brief-June-2020.pdf (accessed on 15 September 2021).

76. Haider, N.; Osman, A.Y.; Gadzekpo, A.; Akipede, G.O.; Asogun, D.; Ansumana, R.; Lessells, R.J.; Khan, P.; Hamid, M.M.A.; Yeboah-Manu, D. Lockdown Measures in Response to COVID-19 in Nine Sub-Saharan African Countries. BMJ Global Health 2020, 5, e003319. [CrossRef]

77. International Labour Organization. Recommendation No. 204 (R204) of 2015; ILO: Geneva, Switzerland, 2015. 